\title{
THE IMPACT OF PRODUCTION AND PRICE RISKS ON THE ECONOMIC BEHAVIOR OF COCONUT FARMERS' HOUSEHOLDS IN SERUYAN REGENCY, CENTRAL BORNEO PROVINCE
}

\author{
Rusdi $^{*}$, Harianto ${ }^{* *}$, Sri Hartoyo ${ }^{* * *}$, Tanti Novianti ${ }^{* * *}$ \\ ${ }^{*}$ University of Pamulang \\ Jl. Surya Kencana No.1, Pamulang, South Tangerang, Banten 15417, Indonesia \\ ${ }^{* *}$ Department of Agribusiness, Faculty of Economics and Management, IPB University \\ Jl. Kamper, IPB Dramaga Campus, Bogor 16680, Indonesia \\ ${ }^{* * *}$ Department of Economics, Faculty of Economics and Management, IPB University \\ Jl. Kamper, IPB Dramaga Campus, Bogor 16680, Indonesia
}

\begin{abstract}
Production risk and price risk are problems that are often faced by coconut farmers. This is illustrated by the price and production instability faced by farmers, which will then have an impact on income and decision making in production and work allocation. The purpose of this study was to analyze the effect of changes in the level of production risk and price on the behavior of farmer households in coconut farming production decisions. This research was conducted in Seruyan Regency, Central Kalimantan Province with a total of 200 farmers as respondents. The production function and the risk function were analyzed using the Ordinary Least Square (OLS) method, while the farmer household economic model which was built using the simultaneous equation would be analyzed using the Two Stage Least Squares (2SLS) method. The results of the risk function analysis show that the risk of coconut production is directly proportional to the use of salt and herbicides. Land area, use of salt, herbicides and labor have a significant and positive effect on coconut production. The simulation results show an increased risk of negative impacts on the economy of coconut farmers' households.
\end{abstract}

Keywords: production risk, price risk, household economy, coconut farmers

\begin{abstract}
Abstrak: Risiko produksi dan risiko harga merupakan permasalahan yang sering dihadapi oleh petani kelapa. Hal ini digambarkan dengan ketidak setabilan harga dan produksi yang dihadapi oleh petani, kemudian akan berdampak pada pendapatan dan pengambilan keputusan dalam produksi dan alokasi kerja. Tujuan penelitian ini adalah untuk menganalisis pengaruh perubahan tingkat risiko produksi dan harga terhadap perilaku rumah tangga petani dalam keputusan produksi usahatani kelapa. Penelitian ini dilakukan di Kabupaten Seruyan, Provinsi Kalimantan Tengah dengan jumlah responden sebanyak 200 petani. Fungsi produksi dan fungsi risiko dianaisis dengan metode Ordinary Least Square (OLS), sedangkan model ekonomi rumah tangga petani yang dibangun dengan persamaan simultan akan dianalisis dengan metode Two Stage Least Squares (2SLS). Hasil analisis fungsi risiko menunjukkan bahwa risiko produksi kelapa berbanding lurus dengan penggunaan garam dan herbisida. Luas lahan, penggunaan garam, herbisida dan tenaga kerja berpengaruh signifikan dan positif terhadap produksi kelapa. Hasil simulasi menunjukkan adanya peningkatan risiko dampak negatif terhadap perekonomian rumah tangga petani kelapa.
\end{abstract}

Kata kunci: risiko produksi, risiko harga, ekonomi rumah tangga, petani kelapa

\footnotetext{
${ }^{1}$ Corresponding author:

Email: rusdi.msi@gmail.com
} 


\section{INTRODUCTION}

Coconut farmers are often faced with risks, including production risk and price risk. The characteristics of the occurrence of production risk and coconut prices can be seen from the instability of production and prices received by coconut farmers every harvest season. This can be seen in (Figure 1), which shows the rise and fall of coconut production and prices. Sources of risk accepted by farmers are weather uncertainty, pest and disease attacks, and product price uncertainty (Patrick et al. 1985). The occurrence of production risk experienced by farmers causes fluctuations in coconut productivity every year.

On the other hand, the risk of product prices can affect the price of products received by farmer households is not stable. This is because the strength of product demand is largely determined by the risk of coconut prices in the market. Based on field observations, the price of coconut in May 2019 was 1,700/grain, but the price of coconut in January only reached 800/grain. Likewise, the coconut production received by farmers every year tends to fluctuate, this indicates a risk, both price and production faced by coconut farmers, which will have an impact on decreasing coconut farmer household income so that it affects the economic behavior of farmer households (Figure 1) .

The existence of fluctuations in coconut production and prices will cause a decrease in coconut farming income which will change economic behavior. So that coconut farmers do not only focus on coconut farming, but some of them work on agricultural activities outside of coconut and some of their household members carry out non-agricultural activities.

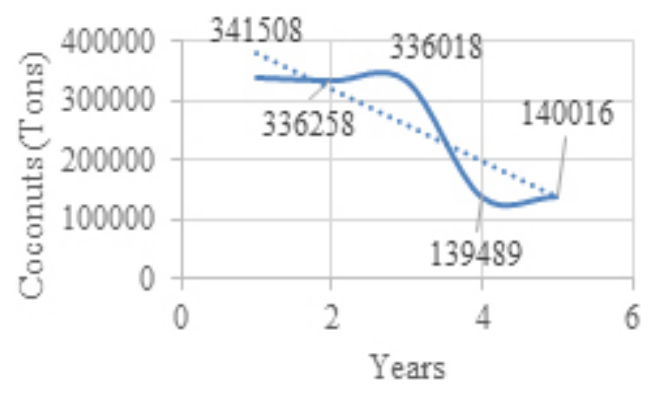

Research related to the effect of production and price risks on the economic behavior of coconut farmers' households is still very limited, especially related to production risks and prices of plantation commodities such as coconut. Previous research such as Fariyanti et al. (2007) and ; Jufri et al. (2018) and Pamusu et al. (2019) is limited to discussing the effect of production risks and commodity prices for seasonal crops, especially vegetables. In this study, data were collected for four harvest seasons in one year. Therefore, research on the effect of production and price risks on plantation commodities is very important.

Nakajima (1986) states that one of the important aspects in studying the agricultural sector in developing countries is the characteristics of the farm household as an interrelated economic unit. For this reason, it is necessary in agricultural policy making to pay attention to the decision-making behavior of farmers, so that in making policies in accordance with the objectives. Research findings, that production and price risks have an impact on the decline in production and household income. This will affect farmer households in making decisions to allocate existing resources (Ellis 1988; Harwood et al. 1999; Fariyanti et al. 2007; Jufri et al. 2018). Therefore, it is important to conduct research on household economic behavior due to production and price risks in coconut farming. So the objectives of this study are: (1) to analyze the factors that influence production risk, (2) to analyze the effect of production risk and price on the economic behavior of coconut farmers' households.

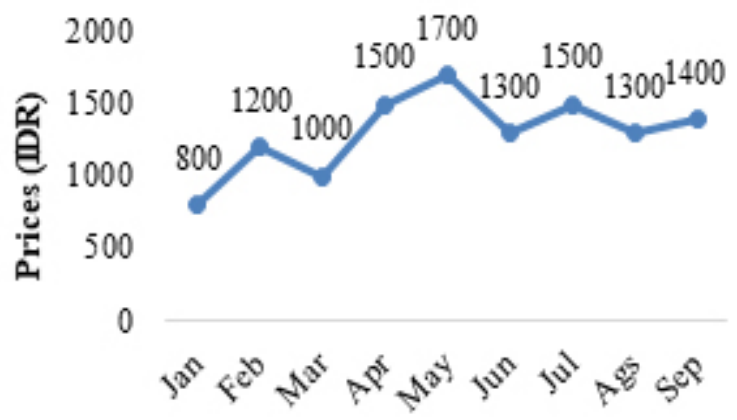

Figure 1. Coconuts production and coconuts prices 


\section{METHODS}

Seruyan Regency as a research place. The location selection was carried out purposively with the consideration that Seruyan Regency is one of the main producers of coconut in Central Kalimantan Province. Based on data from the Directorate General of Plantations in 2019, it is known that Seruyan Regency is the four main producers of coconut in Central Kalimantan with a total area of coconut plantations in 2018 of 1,967 hectares. The study was conducted from February to April 2020.

The data sources used in this study were primary data and secondary data. The type of primary data collected is cross section data for the 2019 planting season. Primary data was obtained through direct interviews with respondents using a questionnaire. Meanwhile, secondary data can be obtained from the Ministry of Agriculture, the Central Statistics Agency and other sources.

The sampling technique was carried out by the multistage purposive sampling method. First, the selection of the research area is Seruyan Regency, Central Kalimantan Province. Second, the selection of sub-districts is based on land area and coconut production. so that the Seruyan Tmur District was selected, where the District is the District with the highest area and production. The third stage is the selection of respondents. Respondents were selected by simple random sampling method based on data from the Agricultural Extension Agency of East Seruyan District. The number of selected respondents is as many as 200 people.

Analysis of the data on the economic model of coconut farmers' households by using simultaneous equations. Thus explaining the relationship between variables in the household economy of coconut farmers. Analysis of the production function and the risk of coconut production and the simultaneous equation model that has been respecified.

To analyze the factors that affect the production faced by coconut farmers, the Just and Pope model of production function is used. This model can explain that production is influenced by the production function and production risk (Robinson and Barry 1987). The production function used in this study is the CobbDouglas production function in the form of the natural logarithm as follows:
LnPROD $=\alpha_{0}+\alpha_{1}^{*} \ln \mathrm{LHKP}+\alpha_{2} * \ln \mathrm{PUGM}+$ $\alpha_{3}^{*} \ln \mathrm{HBSA}+\alpha_{4}{ }^{*} \ln \mathrm{TTKL}+\varepsilon(1)$

Variable description: PROD (Coconut productivity); LHKP (Area of coconut land); PUGM (Use of salt); HBSA (Herbicide use); TTKL (total use of labor for coconut farming).

Furthermore, in this study, the standard deviation is used as production risk by looking at the level of production in each sample from 4 harvest seasons. Determination of high, low and normal production based on the distribution of productivity level data from each season for each sample. Measurement of production risk and expectations is as follows (Robison and Barry 1987):

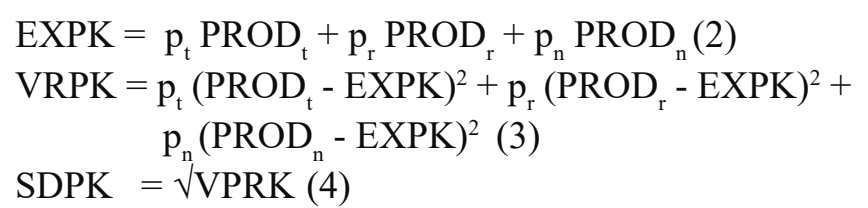

Variable description:

EXPK (coconut production expectation); SDPK (standard deviation of coconut productivity); VRPK (coconut productivity variance); $\mathrm{P}_{\mathrm{t}}$ (high productivity probability); $\mathrm{P}_{\mathrm{r}}$ (Probability for low productivity); $\mathrm{P}_{\mathrm{n}}$ (Probability of normal productivity); PRODt (high coconut productivity); PROD $_{\mathrm{r}}$ (low coconut productivity); $\mathrm{PROD}_{\mathrm{n}}$ (normal coconut productivity).

So the risk function of coconut production is as follows:
$\operatorname{LnSDPK}=\beta_{0}+\beta_{1}{ }^{*} \ln \mathrm{LHKP}+\beta_{2}{ }^{*} \ln \mathrm{PUGM}+$ $\beta_{3}{ }^{*} \ln \mathrm{HBSA}+\beta_{4}{ }^{*} \ln \mathrm{TTKL}+\varepsilon(5)$

\section{Coconut Household Economic Model}

The household economic model of coconut farmers in this study was built in a simultaneous equation system with a total of 30 equations, consisting of 20 structural equations and 10 identity equations as follows:

Coconut Productivity (PROD)

$$
\begin{aligned}
\text { PROD }= & a_{0}+a_{1} \text { *PUGM }+a_{2}{ }^{*} \text { HBSA }+a_{3} * \text { JBKP } \\
& +a_{4} * \text { TPDK }+a_{5} * \text { TWDK }+a_{6} * \text { TTLK }+ \\
& a_{7} \text { *LUTK }+a_{8} \text { *SDPK }+E_{1}(6)
\end{aligned}
$$

Use of salt (PUGM)

PUGM $=b_{0}+b_{1} *$ JBKP $+b_{2} *$ HUGM $+b_{3} *$ UMPK + 
Herbicide use (HBSA)

HBSA $=\mathrm{c}_{0}+\mathrm{c}_{1}{ }^{*}$ HHBS $+\mathrm{c}_{2}{ }^{*}$ LHKP $+\mathrm{c}_{3}{ }^{*}$ TTDK + $\mathrm{c}_{4} *$ TTLK $+\mathrm{c}_{5} * \mathrm{SDPK}+\mathrm{c}_{6} *$ EXHK $+\mathrm{E}_{3}(8)$

The use of male labor in the family in coconut farming (TPDK)

$$
\begin{aligned}
\text { TPDK }= & \mathrm{d}_{0}+\mathrm{d}_{1} * \text { TBUK }+\mathrm{d}_{2} * \text { TPNP }+\mathrm{d}_{3} * \text { EXHK }+ \\
& \mathrm{d}_{4} * \text { EXPK }+\mathrm{d}_{5} * \text { SDPK }+\mathrm{E}_{4}(9)
\end{aligned}
$$

The use of female labor in the family in coconut farming (TWDK)

TWDK $=\mathrm{e}_{0}+\mathrm{e}_{1}$ *TBUK $+\mathrm{e}_{2} *$ TWNP $+\mathrm{e}_{3} *$ EXHK + $\mathrm{e}_{4}^{*} \mathrm{EXPK}+\mathrm{e}_{5}^{*} \mathrm{SDPK}+\mathrm{E}_{5}(10)$

Total use of labor in the family in coconut farming (TTDK)

TTDK $=$ TPDK + TWDK (11)

The use of male labor outside the family in coconut farming (TPLK)

TPLK $=\mathrm{f}_{0}+\mathrm{f}_{1} *$ JBKP $+\mathrm{f}_{2} *$ UTLK $+\mathrm{f}_{3} *$ PTUK + $\mathrm{f}_{4} *$ TPDK $+\mathrm{f}_{5} *$ EXHK $+\mathrm{f}_{6} *$ SDPK $+\mathrm{E}_{6}(12)$

Use of female labor outside the family in coconut farming (TWLK)

TWLK $=\mathrm{g}_{0}+\mathrm{g}_{1}$ *LHKP $+\mathrm{g}_{2}$ *TPLK $+\mathrm{g}_{3}$ *EXPK + $\mathrm{g}_{4} * \mathrm{SDHK}+\mathrm{E}_{7}(13)$

Total use of labor outside the family in coconut farming (TTLK)

TTLK $=$ TPLK + TWLK (14)

The use of male labor in the family in non-coconut farming (TPNK)

TPNK $=\mathrm{h}_{0}+\mathrm{h}_{1}{ }^{*}$ TPNP $+\mathrm{h}_{2}$ *TWNK $+\mathrm{h}_{3}$ *BLUK + $\mathrm{h}_{4} *$ EXHK $+\mathrm{h}_{5} *$ SDHK $+\mathrm{E}_{8}(15)$

The use of female labor in the family in non-coconut farming (TWNK)

TWNK $=\mathrm{i}_{0}+\mathrm{i}_{1}$ *TTNK $+\mathrm{i}_{2}$ *TPDK $+\mathrm{i}_{3}$ *TABP + $\mathrm{i}_{4}{ }^{*} \mathrm{JASE}+\mathrm{i}_{5} * \mathrm{EXHK}+\mathrm{i}_{6} *$ SDHK $+\mathrm{E}_{9}(16)$

Total use of labor in the family in non-coconut farming (TTNK)

TTNK $=$ TPNK + TWNK (17)

The use of male labor in the family in non-agricultural activities kegiatan (TPNP)

TPNP $=\mathrm{j}_{0}+\mathrm{j}_{1} *$ TPNK $+\mathrm{j}_{2} *$ JASE $+\mathrm{j}_{3} *$ JPUT $+\mathrm{j}_{4} *$ PELK

$$
+\mathrm{j}_{5} * \text { EXPK }+\mathrm{j}_{6} * \operatorname{SDHK}+\mathrm{E}_{10}(18)
$$

Use of female labor in the family in non-agricultural activities (TWNP)

TWNP $=\mathrm{k}_{0}+\mathrm{k}_{1}{ }^{*} \mathrm{TTNP}+\mathrm{k}_{2}{ }^{*} \mathrm{TTDK}+\mathrm{k}_{3} *$ ANPR + $\mathrm{k}_{4} *$ PEIS $+\mathrm{k}_{5} *$ EXPK $+\mathrm{k}_{6} *$ SDPK $+\mathrm{E}_{11}(19)$

Total cost of coconut farming (TBUK)

TBUK $=($ PUGM $*$ HUGM $)+($ HBSA $*$ HHBS $)+($ TPLK* UTLK) + (TWLK*UTWT) + BLUK (20)

Coconut farming income (PTUK)

PTUK $=($ PRKP $*$ EXHK $)-$ TBUK $(21)$

Non-coconut farming income (PTNK)

PTNK $=1_{0}+1_{1}$ *UTLK $+1_{2}$ *UTWT $+1_{3}$ *INVES + $1_{4}^{*}$ EXHK $+1_{5}^{*}$ SDHK $+1_{6}^{*}$ SDPK $+E_{12}(22)$

Total income from farming activities (JPUT)

JPUT $=$ PTUK + PTNK (23)

Men's income from non-agricultural activities (PPNP) $\mathrm{PPNP}=\mathrm{m}_{0}+\mathrm{m}_{1}{ }^{*} \mathrm{TPNP}+\mathrm{m}_{2}{ }^{*} \mathrm{UMPK}+\mathrm{m}_{3}{ }^{*} \mathrm{EXPK}+$ $\mathrm{m}_{4}{ }^{*} \mathrm{SDHK}+\mathrm{E}_{13}$

Women's income from non-agricultural activities (PWNP)
PWNP $=\mathrm{n}_{0}+\mathrm{n}_{1}$ *TWNP $+\mathrm{n}_{2}$ *TABP $+\mathrm{n}_{3}$ *INVES $+\mathrm{n}_{4} *$ PEIS $+\mathrm{n}_{5}$ *BLUK $+\mathrm{n}_{6}$ *PPEN + $\mathrm{n}_{7} * \mathrm{KOPG}+\mathrm{E}_{14}(25)$

Women's income from non-agricultural activities (JPNP)

$\mathrm{JPNP}=$ PPNP + PWNP (26)

Total household income (TPRT)

TPRT $=$ JPUT + JPNP (27)

Food consumption (KOPG)

$\mathrm{KOPG}=\mathrm{o}_{0}+\mathrm{o}_{1}$ *JMAK $+\mathrm{o}_{2}{ }^{* T P R T}+\mathrm{o}_{3}$ *EXPK + $\mathrm{o}_{4}{ }^{*} \mathrm{UMPK}+\mathrm{o}_{5}{ }^{* T T D K}+\mathrm{E}_{15}(28)$

Non-food consumption (KNPG)

$\mathrm{KNPG}=\mathrm{p}_{0}+\mathrm{p}_{1}{ }^{*} \mathrm{KOPG}+\mathrm{p}_{2}{ }^{*} \mathrm{TBUK}+\mathrm{p}_{3}{ }^{*} \mathrm{EXHK}+$ $\mathrm{p}_{4}{ }^{*} \mathrm{SDPK}+\mathrm{p}_{5}{ }^{*} \mathrm{TRAN}+\mathrm{E}_{16}(29)$

Total consumption (TKON)

$\mathrm{TKON}=\mathrm{KOPG}+\mathrm{KNPG}(30)$

Health expenses (PKES)

PKES $=\mathrm{q}_{0}+\mathrm{q}_{1}$ *JMAK $+\mathrm{q}_{2}$ *TPRT $+\mathrm{q}_{3}$ *PEIS + $\mathrm{q}_{4} * \mathrm{SDPK}+\mathrm{q}_{5} *$ PPEN $+\mathrm{E}_{17}(31)$ 
Education expenses (PPEN)

PPEN $=\mathrm{r}_{0}+\mathrm{r}_{1}$ *JASE $+\mathrm{r}_{2}$ *JPUT $+\mathrm{r}_{3}$ *PELK + $\mathrm{r}_{4} *$ EXHK $+\mathrm{r}_{5} * \mathrm{SDHK}+\mathrm{r}_{6} * \mathrm{SDPK}+\mathrm{r}_{7} * \mathrm{TPRT}$ $+r_{8} *$ JMAK $+r_{9} *$ TKON $+E_{18}(32)$

Total expenses (TRAN)

TRAN $=$ TKON + PKES + PPEN (33)

Savings (TABP)

TABP $=\mathrm{s}_{0}+\mathrm{s}_{1}$ *TRAN $+\mathrm{s}_{2}$ *TPRT $+\mathrm{s}_{3}$ *PEIS + $\mathrm{s}_{4}{ }^{*} \mathrm{EXHK}+\mathrm{s}_{5} * \mathrm{SDPK}+\mathrm{E}_{19}(34)$

Business investment (INVES)

INVES $=\mathrm{t}_{0}+\mathrm{t}_{1} *$ TABP $+\mathrm{t}_{2} *$ JPNP $+\mathrm{t}_{3} *$ JPUT $+\mathrm{t}_{4} *$ PEIS $*$ $\mathrm{t}_{5} * \mathrm{EXHK}+\mathrm{t}_{6} * \mathrm{EXPK}+\mathrm{t}_{7} * \mathrm{SDHK}+\mathrm{E}_{20}(35)$

Variable description: PRKP (Coconut production); JBKP (Number of productive coconut stalks); LHKP (Area of coconut land); HUGM (Price of salt); HHBS (Herbicide price); BLUK (Other costs of coconut farming); UMPK (farmer's age); ANLK (male labor force); ANPR (female workforce); PEIS (Wife's Education); PELK (Husband's Education); LUTK (Length of Coconut Farming); UTLK (Wages of male TK in farming activities); UTWT (Wages of female TK in farming activities); JASE (Number of school children); JMAK Number of family members).

Simulation analysis is used to clarify the impact of changing variables exogenous and endogenous to all endogenous variables in the model. The simulation analysis in this study focused on changes in the increase in production risk and coconut price risk. Simulations are carried out on: (1) an increase in production risk by 20 percent, (2) an increase in price risk by 20 percent, and (3) a combination of simulations 1 and 2.

The production function and the risk function of coconut production using the Cobb-Douglas production function will be estimated using the Ordinary Least Square (OLS) method. Furthermore, the household economic model of coconut farmers in this study there are 30 equation models $(\mathrm{G})$, there are 20 structural equation models, 10 identity equation models. There are 30 independent variables and 20 dependent variables, the total variables are 50 variables $(\mathrm{K})$. the most variable in the equation is 9 variables $(\mathrm{M})$. The over-identified model, in this case the most appropriate method in taking the method is the Two Stage Least Squares (2SLS) method. Software Statistical Analysis System (SAS) used in data processing. Furthermore, in the validation of the household economic behavior model, Root Mean Square Percented Error (RMSPE) and U-Theil were used.

The existence of production risk which is characterized by fluctuations in coconut production and price risk faced by coconut farmers will have an impact on farm income and household income. So that it will affect the economic behavior of coconut farmer households, namely production decisions, decisions to use labor and consumption decisions. In production decisions, production and price risks will have an impact on the use of the inputs used. Furthermore, the decision to use labor, the limited time they have will cause farmer households to have to allocate their time for coconut farming activities, non-coconut farming and nonagricultural activities. Where an increase in the time allocation for one of these activities will affect the amount of time spent on other activities. The decision on the amount of labor time allocation will have an impact on the income received. So that it will have an impact on the level of household income of coconut farmers. this will certainly affect the decisions for consumption and investment. In detail, the research framework can be seen in Figure 2

Based on the framework that has been explained and the household economic model that has been built, the hypotheses of this study are: (1) input variables such as planting area, salt, herbicides and labor have a significant effect on the production and risk of coconut production, (2) an increase in the risk of coconut production will reduce coconut farming income and household income, so that it will reduce consumption, savings, and investment, and will reduce the allocation of family labor in coconut farming, (3) an increase in price risk will also reduce coconut farming income and household income, so that it will reduce consumption, savings, and investment resulting in a decrease in the welfare of coconut farmers' households. 


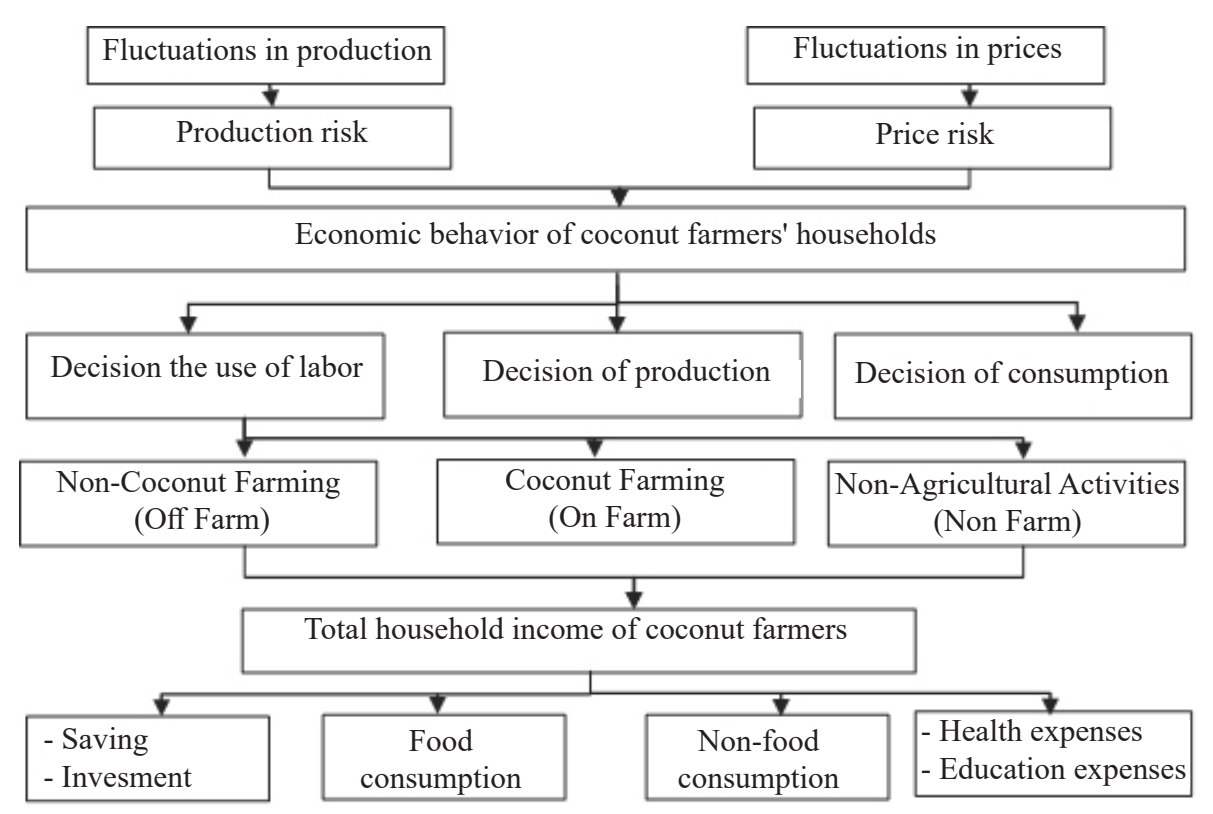

Figure 2. Research framework

\section{RESULTS}

\section{Results of Estimating the Production Function and Risk of Coconut Production}

The results of the estimation of the production function equation and the coconut production risk function can be seen in Table 1. The results of the estimation of the coconut production function show that all explanatory variables have a significant effect on coconut production. The variable area of land has a positive effect on coconut productivity, this shows that the more land owned by coconut farmers, the more coconut productivity will be produced. Based on the results of the study, it is known that the average productivity of coconuts in Seruyan Regency is 4,402 grains/ha with an average coconut area of 2.8 hectares. This is in line with the research of Omar \& Fatah (2021) where the area of coconut plants has a positive effect on coconut production. Further, Apriana et al. 2017) also stated that land area is one of the inputs that has a significant effect on production. The salt variable has a positive effect. This shows that the use of salt as fertilizer for coconut plants can increase the resulting production. Where fertilization using salt can be done 1-2 times for one year with an average use of $83.3 \mathrm{~kg} / \mathrm{ha}$. The results of the study (Fariyanti et al. 2007; Suharyanto et al. 2015; Darmansyah et al. 2017; Yardha et al. 2021) show that increasing the use of urea/nitrogen fertilizer will increase production. The same is true for the use of herbicides, where the use of herbicides also has a positive effect on coconut production. Based on the findings in the field, it shows that the average use of herbicides by farmers is 4.9 liters/ha/year. Herbicide application is usually done once a year. The dose used is very dependent on the level of weed growth and the type of weed. The more and denser the weeds around the coconut plantation, the higher the dose used. The results of this study are in line with Astuti et al. (2019) that increasing herbicides can increase the productivity of shallots. In addition, research by Zakirin et al. (2014) also showed that the use of herbicides will increase rice production. The last explanatory variable is the total use of labor for coconut farming which has a positive effect as well. An increase in the number of workers will increase the maintenance of coconut plantation areas owned by farmers, so that the production results obtained are also increasing. The results of this study are in line with the results of research by Wulandari and Anggraeni (2018), where an increase in the number of workers will increase the productivity of coconut in Kulon Progo Regency. In addition, research results (Fufa and Hassan 2003; Darmansyah et al. 2017; Fariyanti et al. 2007; Suharyanto et al. 2015) show that labor has a significant and positive effect on production.

The results of the analysis of the risk function of coconut production indicate that the explanatory variables that significantly affect production risk are the use of salt and herbicides. The salt variable has a positive effect on the risk of coconut production. This shows that increasing the use of salt will increase the risk of coconut production. This is in line with Hutabarat (1985) that nitrogen and phosphate fertilizers are risk-inducing inputs. The same thing also happened to the results of research by Farnsworth and Moffitt (1981) where an 
increase in the use of fertilizers will cause an increase in the risk of cotton production. The results of the research by Villano and Fleming (2006) where increasing the use of fertilizers will actually increase the risk of rice production. This happens because the increase in the use of too much fertilizer will accelerate plant growth so that it can increase the risk of disease. In addition, the herbicide variable also has a positive effect on the risk of coconut production, which means that herbicide is an input that can increase production risk (risk increasing input). This is contrary to the results of research by Villano and Fleming (2006) which shows that increasing the use of herbicides will actually reduce the risk of rice production. On the other hand, the labor variable has no significant effect on the risk of coconut production in Seruyan Regency. This is in accordance with the results of research (Suharyanto et al. 2015; Yardha et al. 2021) where the use of labor does not significantly affect the level of production risk.

\section{The Impact of Production and Price Risks on the Economic Behavior of Coconut Farmers' Households}

Simulation analysis is used to clarify the impact of changing variables exogenous and endogenous to all endogenous variables in the model. According to Pindyck and Rubinfeld (1991), the purpose of the simulation is divided into two, namely (1) evaluating policies in the past (historical), and (2) forecasting for the future. The simulation analysis in this study focused on changes in the increase in production risk and coconut price risk. The simulation results due to increased risk can be seen in Table 2 .

Table 1. Result of estimation of production function and risk function

\begin{tabular}{|c|c|c|c|c|c|c|c|}
\hline Variable & Coefficient & $\mathrm{T}$ & Prob & Variable & Coefficient & $\mathrm{T}$ & Prob \\
\hline \multicolumn{4}{|c|}{ Coconut Production Function } & \multicolumn{4}{|c|}{ Risk Function } \\
\hline Intercept & 6,4825 & 13,72 & 0,000 & Intercept & 3,2584 & 3,07 & 0,002 \\
\hline LnLHKP & 0,3678 & 3,88 & $0,072 *$ & LnLHKP & $-0,0960$ & $-0,45$ & 0,652 \\
\hline LnPUGM & 0,1315 & 1,81 & $0,002 * * *$ & LnPUGM & 0,4578 & 2,81 & $0,005 * * *$ \\
\hline LnHBSA & 0,3174 & 3,13 & $0,000 * * *$ & LnHBSA & 0,6857 & 3,01 & $0,003 * * *$ \\
\hline LnTTKL & 0,3476 & 4,32 & $0,000 * * *$ & LnTTKL & 0,0746 & 0,41 & 0,679 \\
\hline \multicolumn{4}{|c|}{ R-squared $=0,8444 ; \mathrm{F}$ hit $=264,64 ; \mathrm{Sig}=0,000$} & \multicolumn{4}{|c|}{ R-squared $=0,5454 ; \mathrm{F}$ hit $=\quad 58,48 ; \mathrm{Sig}=0,000$} \\
\hline
\end{tabular}

Table 2. Impact of production and price risks on the economic behavior of coconut farmer households

\begin{tabular}{|c|c|c|c|c|c|c|c|c|c|}
\hline Variable & Basic Value & $\mathrm{S} 1(\%)$ & $\mathrm{S} 2(\%)$ & S3 (\%) & Variable & Basic Value & $\mathrm{S} 1(\%)$ & $\mathrm{S} 2(\%)$ & S3 $(\%)$ \\
\hline PROD & 12349,5 & $-2,32$ & $-0,30$ & 0,82 & PTUK & 333,54704 & $-0,20$ & $-1,66$ & 3,12 \\
\hline PUGM & 220,2 & 0,68 & 0,00 & 0,95 & PTNK & 116,92565 & $-1,63$ & 6,35 & 1,36 \\
\hline HBSA & 13,075 & 1,43 & $-0,09$ & 0,26 & JPUT & 450,47269 & $-2,19$ & $-0,24$ & 3,00 \\
\hline TPDK & 129,7 & $-2,87$ & 0,00 & 0,31 & PPNP & 267,71800 & 0,13 & 0,29 & $-0,85$ \\
\hline TWDK & 22,656 & $-0,17$ & 0,00 & 1,89 & PWNP & 75,10800 & 0,18 & $-0,22$ & 0,55 \\
\hline TTDK & 152,4 & $-2,25$ & 0,00 & 0,67 & TPRT & 793,29869 & $-3,09$ & $-1,03$ & 2,58 \\
\hline TPLK & 146 & 2,06 & $-0,31$ & 0,55 & KOPG & 195,24955 & $-0,21$ & $-3,47$ & 1,61 \\
\hline TWLK & 10,625 & 0,49 & $-7,05$ & 3,63 & KNPG & 106,53932 & $-1,47$ & $-9,72$ & 8,22 \\
\hline TTLK & 156,6 & 1,98 & $-0,45$ & 0,77 & TKON & 301,78878 & $-0,76$ & $-8,44$ & 3,30 \\
\hline TPNK & 95,3995 & 0,68 & 2,44 & 0,16 & PKES & 38,38150 & $-8,81$ & $-2,28$ & 1,74 \\
\hline TWNK & 49,375 & 1,65 & 3,25 & $-0,21$ & PPEN & 51,24485 & $-0,46$ & $-2,98$ & 0,73 \\
\hline TPNP & 106,8 & 0,09 & 0,28 & $-0,55$ & TRAN & 391,41513 & $-6,06$ & $-2,96$ & 6,79 \\
\hline TWNP & 80,46 & 0,18 & $-9,43$ & 0,56 & TABP & 128,43413 & $-2,54$ & $-0,27$ & 0,62 \\
\hline TBUK & 239,87633 & 1,09 & $-0,64$ & 1,01 & INVES & 271,8 & $-0,21$ & $-2,17$ & 0,15 \\
\hline
\end{tabular}

Description: Simulation 1 (Increased production risk by 20\%); Simulation 2 (20\% increase in price risk); Simulation 3 (Combination of simulation 1 and 2) 
An increase in the risk of coconut production by 20 percent causes changes in all household economic variables, both in production decisions, labor allocation and consumption. In making production decisions, the increased risk of coconut production causes coconut farming households to increase the use of production inputs such as salt and herbicides. The increase in the use of these inputs is expected to be able to increase the production of coconut produced, so that the losses that will be experienced by farmers are not too large. This behavior indicates that coconut farming households behave as risk takers, which is indicated by the increased use of coconut production inputs. an increase in the use of these inputs will have an impact on increasing the use of labor from outside the family. In terms of time allocation, an increase in production risk will cause households to reduce the time spent on coconut farming and relocate it to farming activities other than coconut and non-agricultural activities. So that the use of labor in the family for non-coconut farming and non-agricultural activities increases. Furthermore, in taking consumption, the increased risk of coconut production will cause households to reduce food consumption, non-food consumption, health spending and education spending. Expenditure for consumption is strongly influenced by the total income earned by farming households from production activities. This is in line with the research of Pamusu et al. (2019) where production risk will reduce farmer household income. The decrease in income caused by increased production risk causes coconut farming households to reduce consumption. This is in line with (Achmad and Diniyati 2018; Faharuddin et al. 2019; Ningsih et al. (2021) that an increase in household income is one of the most influential factors on household spending for consumption. On the other hand, a decrease in household income also has an impact on savings and business investment made by households.

Furthermore, the simulation results of the increased risk of coconut prices also show results that are relatively the same as the impact caused by the increased risk of production. An increase in the risk of coconut prices will cause coconut farming households to reduce the use of production inputs in the form of the use of herbicides. In making decisions on allocation of time, the risk of coconut prices does not change the use of labor in the family for coconut farming, but there is a decrease in the use of labor for non-coconut farming activities. This is in line with the research of Sidik et al. (2021) that an increase in price risk will make farmers diversify their farming and income sources to anticipate the possibility of total failure in farming. This has an impact on increasing income from non-coconut farming. However, the risk of coconut prices that occur will cause income from coconut farming to decrease. This resulted in a decrease in total household income, although there was an increase in income from noncoconut farming activities. The decline in household income led to a decrease in consumption, savings and business investment.

\section{Managerial Implications}

Production and price risks faced by coconut farming households will change their behavior and reduce their income. So it is necessary to modify land in coconut farming, by combining plants outside of coconut farming, such as bananas. This can increase the income of the farmer, when there is a risk of price and coconut products. In overcoming the decline in prices due to the simultaneous harvest, it is necessary for the local government to regulate the price of coconut in the Seruyan District, so that prices remain stable and farmers are not harmed.

\section{CONCLUSIONS AND RECOMMENDATIONS}

\section{Conclusions}

The risk of coconut production is directly proportional to the use of salt and herbicides. The more use of salt and herbicides, the higher the risk of production. Increased production risk has an impact on increasing the use of inputs and increasing the use of labor from outside the family in coconut farming. However, the increase in production risk causes a decrease in the allocation of labor time in the family for coconut farming and relocating it for non-coconut farming and non-agricultural activities. In addition, an increase in production risk has an impact on a decrease in household income so that consumption also decreases. On the other hand, there is an increase in the risk of coconut prices causing income from coconut farming to decrease. This results in a decrease in total household income which causes a decrease in consumption, savings and business investment. The decrease in savings and investment was as a result of reduced surplus income used as savings and investment. This right is in line 
with Wantasen et al. (2012), Nwibo and Mbam (2013), Abebe (2017) who stated that a decrease in household income would reduce a surplus of income that could be used for savings and business investment.

\section{Recommendations}

It is very important to take anticipatory steps towards handling production risk and price risk. Efforts to handle production risk can be carried out by promoting diversification programs in coconut plantation areas such as intercropping and processing coconut products. Meanwhile, to overcome the risk of product prices, efforts to develop a sales contract system and provide coconut storage facilities and infrastructure. In addition, a joint marketing system through farmer groups and cooperatives can also be carried out to anticipate fluctuations in coconut prices.

\section{ACKNOWLEDGEMENT}

The authors would like to thank the field agricultural extension workers and coconut farmer household respondents in the Seriyan district, Central Kalimantan province. the content of the research is very meaningful for local governments for economic policy making.

\section{REFERENCES}

Abebe A. 2017. Factors affecting rural household saving (in case of Wolayita Zone Ofa Woreda). Journal of Poverty, Investment and Development. 36: 4045.

Achmad B and Diniyati D. (2018). Consumption behaviour of farmer households in Rural Sumbawa. Indonesia. Indonesian Journal of Forestry Research 5(1): 69-80. https://doi. org/10.20886/ijfr.2018.5.1.69-80.

Apriana, N, Fariyanti A, Burhanuddin. 2017. Preferensi risiko petani padi di Daerah Aliran Sungai Bengawan Solo, Kabupaten Bojonegoro, Provinsi Jawa Timur. Jurnal Manajemen \& Agribisnis 14 (2): 165-173. https://doi.org/10.17358/ jma.14.2.165.

Astuti LTW, Daryanto A, Syaukat Y, Daryanto HK. 2019. Analisis risiko produksi usahatani bawang merah pada musim kering dan musim hujan di Kabupaten Brebes. Jurnal Ekonomi Pertanian dan Agribisnis 3(4): 840-852. https://doi. org/10.21776/ub.jepa.2019.003.04.19.

Darmansyah E., Muani A, Radian. 2017. Analisis risiko produksi usahatani jeruk siam pontianak (Citrus nobilis var Microcarpa) di Kabupaten Sambas. Jurnal Social Economic of Agriculture. 6(1):13-23. http://dx.doi.org/10.26418/j.sea. v6i1.21583

Ellis F. 1988. Peasant Economics: Farm Households and Agrarian Development. Cambridge: Cambridge University Press.

Faharuddin, Yunita, Mulyana A, Yamin M. 2019. Agricultural households' food demand: evidence from Indonesia. Asian Journal of Agriculture and Development. 16(2): 45-60. https://doi. org/10.37801/ajad2019.16.2.3.

Fariyanti A, Kuntjoro, Hartoyo S, Daryanto A. 2007. Perilaku ekonomi rumahtangga petani sayuran pada kondisi risiko produksi dan harga di Kecamatan Pangalengan Kabupaten Bandung. Jurnal Agro Ekonomi 25(2): 178-206. http:// dx.doi.org/10.21082/jae.v25n2.2007.178-206

Farnsworth R, Moffitt L. 1981. Cotton production under risk: an analysis of input effects on yield variability and factor demand. Western Journal of Agricultural Economics 6(2): 155-164. https:// doi.org/10.2307/40987539.

Fufa B, Hassan RM. 2003. Stochastic maize production technology and production risk analysis in Dadar District, East Ethiopia. Agrekon 42(2): 116-128. https://doi.org/ 10.1080/03031853.2003.9523615.

Harwood J, Heifner R, Coble K, Perry J, Somwaru A. 1999. Managing risk in farming: concepts. research and analysis. Agricultural Economic Report No. 774. Washington: U.S. Department of Agriculture.

Hutabarat B. 1985. An assessment of farm-level input demands and production under risk on rice farms in the Cimanuk River Basin, Jawa Barat, Indonesia [Ph.D. Dissertation]. Lowa: Lowa State University.

Jufri M, Syaukat Y, Fariyanti A. 2018. Pengaruh risiko produksi terhadap perilaku rumahtangga petani rumput laut di Kabupaten Wakatobi. Jurnal Ekonomi Pertanian dan Agribisnis. 2(5):443-353. $\quad$ https://doi.org/10.21776/ ub.jepa.2018.002.05.10.

Nakajima C. 1986. Subjective Equilibrium Theory of the Farm Household. Amsterdam:Elsevier Science Publishers.

Ningsih M, Suandi, Damayanti Y. 2012. Faktor-faktor 
yang mempengaruhi pola konsumsi pangan dan gizi rumah tangga nelayan Kecamatan Tungkal Ilir . Jurnal Sosio Ekonomika Bisnis 15(1). 4856. https://doi.org/10.22437/jiseb.v15i1.2742.

Nwibo SU, Mbam BN. 2013. Determinants of savings and investment capacities of farming households in Udi Local Government Area of Enugu State, Nigeria. Research Journal of Finance and Accounting 4(15): 59-68.

Omar Z, Fatah FA. 2021. Determinants of Technical Efficiency Among Coconut Smallholder Production in Johor, Malaysia: A Cobb Douglas Stochastic Frontier Production Approach. IOP Conf. Series: Earth and Environmental Science 757:1-10. doi:10.1088/1755-1315/757/1/012013

Pamusu SS, Harianto, Kuntjoro, Winandi R. 2019. Dampak risiko produksi terhadap kesejahteraan rumahtangga petani bawang merah di Kabupaten Sigi. Jurnal Ekonomi Pertanian dan Agribisnis 3(2): 429-438. https://doi.org/10.21776/ ub.jepa.2019.003.02.18.

Patrick GR, Wilson PH, Barry PJ, Bogges WG, Young DL. 1985. Risk perceptions and management response: producer-generated hypotheses for risk modelling. Journal Agricultural Economics 17(2): 231-238. https://doi.org/10.22004/ ag.econ.29989.

Robison, LJ, Barry PJ. 1987. The Competitive Firm's Response to Risk. New York: Macmillan Publisher.
Suharyanto, Rinaldy J, Ngurah NA. 2015. Analisis risiko produksi usahatani padi sawah. AGRARIS: Journal of Agribusiness and Rural Development Research 1(2): 70-77. https://doi.org/10.18196/ agr.1210.

Villano R, Fleming E. 2006. Technical inefficiency and production risk in rice farming: evidence from Central Luzon Philippines. Asian Economic Journal 20(1):29-46. https://doi.org/10.1111/ j.1467-8381.2006.00223.x

Wantasen E, Hartono B, Hanani N, Panelewen VVJ. 2012. Household economic behavior of traditional cattle farmers in utilizing artificial insemination technology: A case study in village of Kanonang III. Minahasa Regency of Indonesa. Journal of Agriculture and Food Technology 2(8): 141-152.

Wulandari K, Anggraeni R. 2018. Analisis faktor yang memengaruhi produktivitas kelapa di Kecamatan Panjatan, Kabupaten Kulon Progo. Jurnal Pertanian Agros 20(1): 29-38.

Yardha, Wahyudi E, Wafi A. 2021. Analysis on factors affecting the risk of rice farming production in West Tanjung Jabung Regency. IOP Conf. Series: Earth and Environmental Science 715(1): 1-12. https://doi.org/10.1088/17551315/715/1/012009

Zakirin M, Yurisinthae E, Kusrini N. 2014. Analisis risiko usahatani padi pada lahan pasang surut di kabupaten pontianak. Jurnal Social Economic of Agriculture 2(1): 75-84. http://dx.doi. org/10.26418/j.sea.v2i1.5122. 